\title{
POLITICS AND UTOPIA
}

Washington, D. C. SIR: I agree wholeheartedly with the main thrust of Mr. Thomas Molnar's attack on utopianism in international dealings (Worldview, January, 1959). Because I agree, I am particularly disappointed that he has weakened the force of his argument by staking out needlessly rigid positions on certain secondary issues, especially Quemoy and Algeria.

Concerning Quemoy, he writes: "The military importance of the off-shore islands may be great or little. The prestige of the Western powers in general, and of the United States in particular-their ability to stand by their friends-is, on the other hand, enormously important ... Then Mr. Molnar moves on to other issues, but I do not think the subject can be left there. It is precisely because the off-shore islands are now worthless and may very soon be militarily indefensible that I and many others object to mortgaging Western prestige to their defenses.

Our prestige is important and ought not to be committed lightly. Berlin and South Korea and Formosa, for example, may be hard to defend but they are prizes worth defending and have symbolic and material value that makes them worth taking a stand for-Quemoy and Matsu do not. Neither did the Tachens which were abandoned with no loss back in 1955. The off-shore islands should not have been abandoned last fall when under direct fire but now that the crisis has once again abated, we should strengthen our position by liquidating the worthless and the potentially indefensible.

My second objection is to the identification Mr. Molnar makes between maintaining a firm Western position and the hanging-on of the French in Algeria. I agree that France is very important to the Western alliance. I think Algeria should be allowed its freedom because I think the Algerian War is draining France of vital strength. Money squandered in the desert war could be used to modernize the French industries, to end the chronic housing shortage, to build the laboratories and school facilities that would enable France to achieve new scientific and technological eminence.

Let us not forget that it is an entire generation of young French men and women who are paying for the Algerian War very dearly in terms of lost opportunities in education, in science, and in industry. This is the view of Mendes-France and, one suspects, of de Gaulle himself. No one should believe that the F.L.N. would usher in a democratic utopia if Algeria were free of French control-on this point Mr. Molnar is right. But likewise no one, in my opinion, should believe that the long, bloody, expensive war to impose on Algeria a control the majority do not want is strengthening France or the West.

Notwithstanding these dissents to the way in which Mr. Molnar applies his general views, I want; to reiterate my agreement with those views and to congratulate him for his vigorous, persuasive statement of them.

WILLIAM V. SHANNON The New York Post

MR. MOLNAR REPLIES: I was surprised to read the editorially added sub-title to my article on "Polltics and Utopia" (January, 1959), according to which in my view "power has its own morality." This I never said, this I do not believe. On the contrary, I believe that power and morality are two distnct realities (which must come to terms at some point), and that nations and statesmen must apportion them judiciously in their realistic conduct of international transactions.

Worlduiew, in its January editorial Varieties of Utopianism," and Mr. Herman Reissig in his letter published last month, criticize me on two points: first, that when I attack the utopians in our midst, I "beat an almost-dead horse"; and second, that I attribute to power an almost exclusive role in international affairs: "without limits," as Mr. Reissig states.

Now I agree that nobody has ever seen a "utopian" in the purely distilled condition in which my opponents demand that I exhibit one. (The poor creature would long ago have evaporated and would now be waiting for us in its nowhere paradise.) But I do know many people whom I may, in good conscience, call utopians in the given situations I mentioned in the article, and other, similar situations: those who would give up, or make concessions on Berlin and Formosa, who stress for unilateral nuclear disarmament (Linus Pauling and Bertrand Russell among them), who believe that with every new African 